Валентина ТЮРІНА, orcid.org/0000-0003-2308-1977 доктор педагогічних наук, професор, професор кафедри соиіології та психології Харківського національного університету внутрішніх справ (Харків, Україна) turinavale@gmail.com

\title{
ФОРМУВАННЯ В МАЙБУТНІХ ОФІЦЕРІВ ПОЛІЦІЇ ГОТОВНОСТІ ДО РОБОТИ З ПОПЕРЕДЖЕННЯ НАСИЛЬСТВА В СІМ'Ї
}

\begin{abstract}
Стаття присвячена актуальній проблемі формування в курсантів як майбутніх офіцерів поліції готовності до роботи з попередження насильства в сім'ї. Показано, щзо готовність є інтегративною якістю особистості, психологічною основою якої є змога і прагнення здійснювати якусь певну діяльність. Отже, готовність до виконання певної діяльності базується на певних знаннях, уміннях, навичках та якостях особистості. Отже, готовність до роботи з попередження насильства в сім'ї має базуватися на знаннях про насильство та профілактичну роботу, на вміннях протидіяти насильству та попереджати його, на певних якостях особистості, до яких належить, зокрема, готовність до роботи з попередження насильства в сім $̈$. Показано, щио нині служби дільничних інспекторів поліиії, служби кримінальної поліиії у справах неповнолітніх, куди здебільшого звертаються потерпілі від насильства в сім'ї, спрямовують свою роботу на виявлення фактів насильства в сім'ї та покарання насильників. Профілактична робота з попередження насильства в сім'ї здійснюється в основному кризовими иентрами й центрами медико-соціальної реабілітації як реалізація вторинної та третинної профілактики. Наше дослідження показало, що більш доцільним є здійснення первинної профілактики, яку варто проводити з населенням, особливо з молоддю. Така робота, насамперед, передбачає роботу зі старшокласниками, студентами, курсантами. Саме ичі молоді люди створюють нові сім'ї і нові сімейні традицї, використовуючи стереотипи поведінки, що були засвоєні в їхніх батьківських сім'ях. А иеей досвід $і$ запозичені стереотипи далеко не завжди є позитивними. Результати дослідження свідчать, щзо найвищі результати в процесі формування знань, умінь, навичок, а отже, й готовності як якості особистості, були одержані в експериментальній групі $\left(E_{2}\right)$. У иій групі, на відміну від інших, проводились ще й педагогічна практика в старших класах загальноосвітніх шкіл, метою якої було поглиблення знань, одержаних під час аудиторних занять, та відпрацяювання умінь $і$ навичок здійснення первинної профілактики насильства в сім'ї.
\end{abstract}

Ключові слова: насильство, насильство в сім'ї, профілактика, готовність до роботи з профілактики насильства в сім $\dddot{\imath}$.

Valentyna TYURINA, orcid.org/0000-0003-2308-1977 Doctor of Pedagogical Sciences, Professor, Professor of the Department of Sociology and Psychology Kharkiv National University of Internal Affairs (Kharkiv,Ukraine) turinavale@gmail.com

\section{FORMATION IN FUTURE POLICE OFFICERS OF READINESS FOR WORK TO PREVENT DOMESTIC VIOLENCE}

The article deals with the urgent problem of forming cadets as future police officers 'readiness to work to prevent domestic violence. Willingness is shown to be an integrative quality of personality, the psychological basis of which is the ability and desire to carry out some specific activity. So, readiness to perform a certain activity is based on certain knowledge, skills, skills and qualities of the individual. Thus, the willingness to work to prevent domestic violence must be based on knowledge of violence and preventive work, the ability to counteract violence and to prevent it, certain qualities of the person to which it relates, in particular the willingness to work on the prevention of domestic violence. It is shown that today the services of district police inspectors, the services of the criminal police in the cases of minors, where in most cases victims of domestic violence are turning their work to identify Domestic violence prevention and punishment: Preventive work on preventing domestic violence is carried out mainly by crisis and medico-social rehabilitation centers as a secondary and tertiary prevention exercise. Such work, first of all, involves working with high school students, students, cadets. It is these young people who create new families and new family traditions, using the stereotypes of behavior that have been learned in their parent families. And this experience and borrowed stereotypes are not always positive. The results of the study indicate that the highest results in the formation of knowledge, skills, skills, and, consequently, readiness as a quality of personality, were obtained in the experimental group (E2). In this group, unlike others, pedagogical practice was also carried out in the upper classes of comprehensive schools, the purpose of which was to deepen the knowledge obtained during the classroom, and to develop the skills and skills of primary prevention of domestic violence.

Key words: violence, domestic violence, prevention, willingness to work to prevent domestic violence. 
Постановка проблеми. Однією 3 актуальних проблем, що потребує вивчення, є проблема насильства в сім'ї. Результати аналізу статистичних даних свідчать, що найбільша кількість тяжких правопорушень проти особистості відбувається у сфері сімейно-побутових відносин.

Важливу роль у зниженні соціальної напруженості, використанні мирних засобів і методів вирішення сімейних конфліктів, попередженні їх кримінального розвитку покликані відігравати правоохоронні органи, які мають змогу і зобов'язані проводити з населенням профілактичну роботу, що спрямована на попередження насильства в сім'ї.

Аналіз досліджень. Проблема формування в курсантів як майбутніх офіцерів поліції готовності до професійної діяльності в різних сферах була предметом дослідження багатьох учених: в юридичній галузі - Г. І. Васильєв, Н. Л. Горбач, В. І. Дяченко, Г. Є. Запорожцева, А. С. Морозов та ін.; в педагогічній галузі О. О. Абдуліна, І. М. Богданова, І. Я. Зязюн, Т. О. Ільїна, Н. В. Кузьміна, А. Ф. Ліненко, Л. Ф. Спірін, В. О. Тюріна, Р. І. Хмелюк, П. Д.Червоний та ін. Фундаментальні основи сучасних теорій насильства були закладені в дослідженнях Х. Арангурена, Г. Блумера, М. Вебера, Д. Галтунга, Л. Гумпловича, Е. Дюркгейма, Г. Зіммеля, К. Маркса, Р. Мертона, У. Самнера, Н. Смелзера, П. Сорокіна, О. Шпенглера та ін.

Проблему насильства в сім'ї розглядають у роботах зарубіжні та вітчизняні спеціалісти різних галузей наук: юристи (Е. І. Скакунов, В. А. Туляков), психологи (І. Д. Бех, О. І. Захаров, О. Б. Орлов, О. О. Кочемирівська, 3. Фройд, Е. Фромм, Е. Міллер, Л. Берковіц, М. Страус, Н. Блеклок), педагоги (Л. С. Нечепоренко, Н. Опухова, І. А. Хозраткулова, В. В. Радул,), соціологи (А. А. Бесєдін, О. В. Бойко, В. М. Закірова, Р. Коллінз, Г. Паттерсон, Т. В. Шипунова) та інші дослідники. Насильство у сфері шлюбносімейних відносин із позицій конфліктології вивчалося А. Я. Анцуповим, А. Г. Здравомисловим, А. М. Ніколаєвською, Л. А. Петровською, Т. М. Титаренко, А. І. Шипіловим та ін.

Попри фундаментальність означених праць, мало розробленими залишилися питання, пов'язані з профілактикою насильства в сім'ї, зокрема питання формування в курсантів як майбутніх працівників поліції готовності до роботи 3 попередження насильства в сім'ї, оскільки вирішенням проблеми насильства в сім'ї правоохоронці почали займатися після набуття чинності Законом України «Про попередження насильства в сім'ї» від 15 листопада 2001 р., тобто порівняно недавно.

Мета статті полягає в тому, щоб показати доцільність раціональної організації навчальнопізнавальної діяльності курсантів із метою формування в них готовності до роботи 3 попередження насильства в сім'ї.

Виклад основного матеріалу. Реалізація профілактичних заходів, спрямованих на попередження насильства в сім'ї, державою покладена в основному на служби дільничних інспекторів поліції, служби кримінальної поліції у справах неповнолітніх, куди здебільшого звертаються потерпілі від насильства в сім'ї [1]. Робота цих служб в основному орієнтована на виявлення фактів насильства в сім'ї та покарання насильників, інші ж установи (кризові центри й центри медико-соціальної реабілітаціiі) займаються нівелюванням наслідків уже скоєного насильства.

Таким чином, вирішення проблеми насильства в сім’ї орієнтоване переважно на усунення наслідків насильства, тобто спрямоване на здійснення вторинної та третинної профілактики.

Проте, на нашу думку, що для того щоб зменшити кількість випадків насильства в сім'ї, працівникам поліції разом із соціальними психологами i педагогами доцільно проводити 3 населенням первинну профілактику, яка має бути спрямована саме на попередження, тобто завчасну ліквідацію і відвернення умов, що провокують появу криміногенно небезпечних явищ, які можуть сприяти виникненню насильства в сім'ї.

Така профілактична робота має проводитися 3 правослухняною категорією громадян і благополучними сім'ями. Особливо ефективною, на нашу думку, може виявитися робота з молоддю, зокрема старшокласниками, студентами та курсантами, оскільки саме молодь створює нові сім'ї, а отже, й власні сімейні традиції, переносячи у свою нову сім'ю стереотипи поведінки, що були засвоєні під час спілкування $з$ однолітками або в батьківських сім'ях. А цей досвід i запозичені стереотипи далеко не завжди $€$ позитивними.

Однією 3 особливостей роботи працівників поліції 3 населенням, зокрема попередження насильства в сім'ї, $є$ те, що вона потребує реалізації педагогічної функції в процесі професійно-педагогічної підготовки курсантів, результатом якої є готовність до здійснення професійної діяльності, а отже, й готовність до роботи 3 попередження насильства в сім'ї. 
Готовність - це якість особистості, психологічною основною якої $є$ здатність і прагнення ефективно й результативно виконувати певну діяльність. Отже, готовність передбачає наявність, сформованість системи знань, умінь і навичок, а також певних якостей особистості.

3 огляду на це, ми вважаємо, що готовність до роботи $з$ попередження насильства в сім'ї потребує сформованості в курсантів як майбутніх працівників поліції системи знань про те, що таке «насильство» взагалі і «насильство в сім'ї» зокрема, які є види насильства в сім'ї, які умови і фактори провокують його виникнення, а також системи знань із питань профілактики. Це передбачає формування цілого комплексу відповідних умінь щодо результативного здійснення профілактичної роботи з попередження насильства в сім'ї, а також комплексу певних якостей особистості, що сприяють підвищенню якості вказаної роботи.

Як і будь-яка інша якість особистості, готовність формується в процесі діяльності, зокрема навчально-пізнавальної діяльності, i, як результат цієї діяльності, залежить від особливостей їі організації $[2 ; 3]$.

Отже, готовність майбутніх правоохоронців до професійної діяльності, в тому числі й до роботи 3 попередження насильства в сім’ї, теж формується в процесі навчально-пізнавальної та відповідної практичної діяльності, а рівень сформованості готовності визначається особливостями організації означених діяльностей $[2 ; 3]$.

Виходячи із зазначеного, вважаємо, що раціональна організація навчально-пізнавальної діяльності курсантів як майбутніх офіцерів поліції має здійснюватися з урахуванням психологічних закономірностей засвоєння навчальної інформації, формування системних знань, умінь і навичок.

Вважаємо, що вихідними психолого-педагогічними положеннями, які дають змогу раціонально організувати навчально-пізнавальну діяльність курсантів, є такі:

1) знання $\epsilon$ результатом власної активної самостійної розумової навчально-пізнавальної діяльності людини;

2) мислити людина починає тільки за умов задачі;

3) активність мисленнєвої діяльності значно зростає за наявності проблемної ситуації;

4) чим більше розбіжність, що створена протиріччями у проблемній ситуації, тим активніше мислить людина [2].
Разом із тим необхідно враховувати, що навчально-пізнавальна діяльність, як і будьяка інша діяльність, має такі структурні компоненти: мотиваційний, орієнтаційний (цільовий), змістовно-операційний, енергетичний (вольовий), контрольно-оцінний. Тобто вдосконалення навчально-пізнавальної діяльності полягає у формуванні та вдосконаленні цих компонентів.

Велике значення для формування готовності до виконання будь-якої діяльності має практична діяльність, зокрема проходження курсантами практики. Таку практику майбутні офіцери поліції можуть проходити в центрах медикосоціальної реабілітації і кризових центрах.

Але уміння і навички здійснювати первинну профілактику насильства в сім'ї доцільно формувати в курсантів соціально-психологічних факультетів в процесі проходження педагогічної практики в загальноосвітніх школах. Тут вони можуть працювати з чисельним різноманітним контингентом молоді, яка невдовзі створюватиме власні сім’ї. Саме для старшокласників, як свідчить наш досвід, питання, що стосуються поведінки в сім'ї, сімейних відносин, змоги зберегти почуття, що були до вступу в шлюб, психології сім'ї, $є$ актуальними й активно обговорюються особливо 3 курсантами-практикантами, оскільки спрацьовує принцип «рівний рівному», коли виникає більше довіри саме до курсантів, які ненабагато старші за учнів-старшокласників, ніж до вчителя.

Ефективність формування в курсантів Харківського національного університету внутрішніх справ готовності до роботи 3 попередження насильства в сім'ї підтверджується результатами нашого дослідження.

У процесі експериментальної роботи було виділено дві експериментальні групи $\left(\mathrm{E}_{1}\right)$ i $\left(\mathrm{E}_{2}\right)$ та контрольну групу (К) курсантів, в якій навчання велось традиційними методами. У другій експериментальній групі $\left(\mathrm{E}_{2}\right)$, на відміну від першої експериментальної групи $\left(\mathrm{E}_{1}\right)$, крім проведення спецкурсу «Професійно-педагогічна підготовка до попередження насильства в сім'ї», написання курсових та дипломних робіт з означеної проблеми та проведення тренінгу, проводилась ще й педагогічна практика в старших класах загальноосвітніх шкіл, метою якої було поглиблення знань, одержаних під час аудиторних занять, та відпрацювання умінь і навичок здійснення первинної профілактики насильства в сім’ї. Одержані результати щодо формування готовності до роботи 3 попередження насильства в сім'ї представлені у таблицях 1 i 2 . 
Тюріна В. Формування в майьутніх офицерів помиції готовності мо роботи...

Таблиця 1

Визначення рівня сформованості обсягу знань із проблеми насильства в сім'ї до та після проведення експерименту (у \%)

\begin{tabular}{|c|c|c|c|c|c|c|}
\hline \multirow[b]{2}{*}{$\begin{array}{l}\text { № } \\
\text { 3/II }\end{array}$} & \multirow[b]{2}{*}{ Група } & \multirow{2}{*}{$\begin{array}{c}\text { Етапи } \\
\text { експерименту / } \\
\text { приріст }\end{array}$} & \multicolumn{4}{|c|}{ Рівні } \\
\hline & & & Нульовий & $\begin{array}{c}\text { Низький } \\
\text { (завд. № 1) }\end{array}$ & $\begin{array}{c}\text { Середній } \\
\text { (завд. № 2) }\end{array}$ & $\begin{array}{c}\text { Високий } \\
\text { (завд. № 3) }\end{array}$ \\
\hline 1 & \multirow{3}{*}{$\begin{array}{c}E_{1} \\
\text { (112 ociб) }\end{array}$} & Початок & 28,57 & 51,79 & 18,75 & 0,89 \\
\hline 2 & & Кінець & 0 & 59,82 & 26,78 & 13,4 \\
\hline 3 & & Приріст & $-28,57$ & $+8,03$ & $+8,03$ & $+12,51$ \\
\hline 4 & \multirow{3}{*}{$\begin{array}{c}E_{2} \\
\text { (156 осіб) }\end{array}$} & Початок & 43,59 & 39,74 & 16,67 & 0 \\
\hline 5 & & Кінець & 1,92 & 51,28 & 36,54 & 10,26 \\
\hline 6 & & Приріст & $-41,67$ & $+11,54$ & $+19,87$ & $+10,26$ \\
\hline 7 & \multirow{3}{*}{$\begin{array}{c}\text { K } \\
\text { (46 осіб) }\end{array}$} & Початок & 34,78 & 50,0 & 10,87 & 4,35 \\
\hline 8 & & Кінець & 6,52 & 60,87 & 26,09 & 6,52 \\
\hline 9 & & Приріст & $-28,26$ & $+10,87$ & $+15,22$ & $+2,17$ \\
\hline
\end{tabular}

Таблиця 2

Визначення рівня сформованості професійних вмінь здійснювати роботу з попередження насильства в сім'ї до та після проведення спецкурсу (у \%)

\begin{tabular}{|c|c|c|c|c|c|c|}
\hline \multirow[b]{2}{*}{$\begin{array}{l}\text { № } \\
\text { 3/II }\end{array}$} & \multirow[b]{2}{*}{ Група } & \multirow{2}{*}{$\begin{array}{c}\text { Етапи } \\
\text { експерименту / } \\
\text { приріст }\end{array}$} & \multicolumn{4}{|c|}{ Рівні } \\
\hline & & & Нульовий & $\begin{array}{c}\text { Низький } \\
\text { (завд. № 1) }\end{array}$ & $\begin{array}{c}\text { Середній } \\
\text { (завд. № 2) }\end{array}$ & $\begin{array}{c}\text { Високий } \\
\text { (завд. № 3) }\end{array}$ \\
\hline 1 & \multirow{3}{*}{$\begin{array}{c}E_{1} \\
\text { (112 осіб) }\end{array}$} & Початок & 32,14 & 50,9 & 16,96 & 0 \\
\hline 2 & & Кінець & 0 & 63,4 & 24,1 & 12,5 \\
\hline 3 & & Приріст & $-32,14$ & $+12,5$ & $+7,14$ & $+12,5$ \\
\hline 4 & \multirow{3}{*}{$\begin{array}{c}E_{2} \\
(156 \text { осіб) }\end{array}$} & Початок & 46,15 & 39,1 & 14,75 & 0 \\
\hline 5 & & Кінець & 0,64 & 46,8 & 42,3 & 10,26 \\
\hline 6 & & Приріст & $-45,51$ & $+7,7$ & $+27,55$ & $+10,26$ \\
\hline 7 & \multirow{3}{*}{$\begin{array}{c}\text { K } \\
(46 \text { осіб) }\end{array}$} & Початок & 41,3 & 47,8 & 8,7 & 2,2 \\
\hline 8 & & Кінець & 10,87 & 58,69 & 26,09 & 4,35 \\
\hline 9 & & Приріст & $-30,43$ & $+10,89$ & $+17,39$ & $+2,15$ \\
\hline
\end{tabular}

Висновки. Таким чином, раціональна організація навчально-пізнавальної діяльності курсантів, зокрема проходження ними педагогічної практики в загальноосвітніх школах із метою проведення роботи 3 профілактики насильства в сім'ї, сприяє якісному формуванню в майбутніх офіцерів поліції професійних знань, умінь та навичок щодо роботи 3 попередження насильства в сім'ї, а отже, готовності до виконання цієї роботи.

\section{СПИСОК ВИКОРИСТАНИХ ДЖЕРЕЛ}

1. Про попередження насильства в сім’ї : Закон України від 15 листопада 2001 р.

2. Рубинштейн С. Л. Проблемы общей психологии. Москва : Педагогика, 1973.

3. Тюріна В. О. Пізнавальна самостійність школярів. Харків : Основа, 1993.

\section{REFERENCES}

1. Pro poperedzhennya nasyl'stva v sim' yi [Law of Ukraine "On Prevention of Domestic Violence"] : Zakon Ukrayiny vid 15 lystopada 2001 r. Kiev, 2001. [ in Ukrainian]

2. Rubynshteyn S. L. Problemy obshchey psykholohyy. [Problems of general psychology]. Moskva : Pedahohyka. 1973. [ in Russian]

3. Tyurina V. A. Poznaval'naya samostoyatel'nost' shkol'nykov. [Cognitive independence of schoolchildren]. Kharkiv : Osnova, 1993. [in Ukrainian]. 